\title{
BRD4 and Cancer: going beyond transcriptional regulation
}

\author{
Benedetta Donati ${ }^{\dagger}$, Eugenia Lorenzini ${ }^{\dagger}$ and Alessia Ciarrocchi ${ }^{*}$ (D)
}

\begin{abstract}
BRD4, member of the Bromodomain and Extraterminal (BET) protein family, is largely acknowledged in cancer for its role in super-enhancers (SES) organization and oncogenes expression regulation. Inhibition of BRD4 shortcuts the communication between SEs and target promoters with a subsequent cell-specific repression of oncogenes to which cancer cells are addicted and cell death. To date, this is the most credited mechanism of action of BET inhibitors, a class of small molecules targeting BET proteins which are currently in clinical trials in several cancer settings. However, recent evidence indicates that BRD4 relevance in cancer goes beyond its role in transcription regulation and identifies this protein as a keeper of genome stability.

Indeed, a non-transcriptional role of BRD4 in controlling DNA damage checkpoint activation and repair as well as telomere maintenance has been proposed, throwing new lights into the multiple functions of this protein and opening new perspectives on the use of BETi in cancer. Here we discuss the current available information on non-canonical, non-transcriptional functions of BRD4 and on their implications in cancer biology. Integrating this information with the already known BRD4 role in gene expression regulation, we propose a "common" model to explain BRD4 genomic function. Furthermore, in light of the transversal function of BRD4, we provide new interpretation for the cytotoxic activity of BETi and we discuss new possibilities for a wide and focused employment of these drugs in clinical settings.
\end{abstract}

Keywords: BRD4, BET inhibitors, Transcriptional regulation, DNA damage response, Telomere regulation, Unconventional function, Cancer

\section{Introduction}

BRD4 is a transcriptional and epigenetic regulator that plays a pivotal role during embryogenesis and cancer development. As the other members of the Bromodomains and Extraterminal (BET) family (BRD2, BRD3 and the testis-ovary specific BRDT), BRD4 is characterized by two tandem bromodomains (BD1, BD2). $\mathrm{BDs}$ bind acetylated lysine residues on target proteins, including histones [1-3]. Being their affinity higher for proteins with multiple acetylated residues, BRD4 and the other BET proteins, interact with hyper-acetylated histone regions along the chromatin, accumulating on transcriptionally active regulatory elements and promoting gene transcription both at initiation and elongation step [4-6].

\footnotetext{
* Correspondence: Alessia.Ciarrocchi@ausl.re.it

†Benedetta Donati and Eugenia Lorenzini contributed equally to this work. Laboratory of Translational Research, Azienda Unità Sanitaria Locale-IRCCS di Reggio Emilia, Viale Risorgimento 80, 42123 Reggio Emilia, Italy
}

Genome wide studies indicate that BRD4 is widely distributed along the genome. However, cancer associated genes seem to be selectively dependent on BRD4 being c-MYC the paradigm of this model [7]. For this reason, inhibition of BRD4 by the use of the recently developed BET-inhibitors (BETi), is currently regarded as one of the most promising strategy to target both hematological and solid malignancies. These molecules mimic the acetyl moiety, occluding the acetyl-lysine binding pocket unique of the BET family proteins, displacing them from chromatin [8-12]. Recent evidence adds further complexity on the role of BRD4 in cancer, showing that this protein plays additional non-transcriptional functions, affecting processes like DNA damage repair and checkpoint activation or telomere homeostasis. BETi mediated inhibition of these BRD4 non-canonical activities could significantly impact on cancer cells growth and survival. In the present work, we attempt to discuss the most recent evidence of a

(C) The Author(s). 2018 Open Access This article is distributed under the terms of the Creative Commons Attribution 4.0 International License (http://creativecommons.org/licenses/by/4.0/), which permits unrestricted use, distribution, and 
transversal function of BRD4 in keeping genome stability providing new insights into the cytotoxic effects of BETi in cancer cells.

\section{BRD4 and transcription regulation}

BRD4 was first identified as a cell cycle controlling protein, which associates with chromosomes during mitosis to mark genes whose ready transcription in G1 is required to ensure cell cycle progression [13-16]. From these original observations the relevance and the complexity of BRD4 in transcription regulation has grown exponentially (Table 1 ). The transcriptional activity of BRD4 is essential during embryogenesis [1719] and for cell identity determination. In the early phases of embryogenesis, BRD4 is required to maintain Embryonic Stem Cells (ESCs) self-renewal and pluripotency by controlling or cooperating with ESC TFs like Nanog [18] and OCT4 [19]. In mice, Brd4-null embryos die shortly after implantation due to their inability to maintain the inner cell mass, which gives rise to ESCs [20]. Later during development BRD4 is essential for cell identity determination through the selective regulation of lineage-specific genes. Lee and colleagues using two conditional knockout mouse models showed that BRD4 expression is required for adipogenesis and myogenesis [21]. As well, Najafowa et al. using human fetal osteoblasts demonstrated that BRD4 activity perturbation impairs the entire osteoblast differentiation process from the early commitment to the late phases of mineralization and bone formation [22]. All these studies converge on a common model: BRD4 accumulates on a specific subset of lineage specific, context dependent ENHs through the interaction with lineage specific TFs, facilitating the expression of cell-identity genes. BRD4 is a transcription activator, even if scattered evidence indicates that BRD4 may work occasionally as transcriptional repressor [6, 23]. As reader of the histone code, BRD4 accumulates on hyper-acetylated and transcriptionally prone chromatin regions (both promoters and ENHs) working as nucleation center for the assembly of large protein complexes that promote RNA-PolII activity stimulating transcription initiation and elongation (Fig. 1a). This function largely but not entirely relies on BRD4 BDs and on their ability to recognize acetyl-proteins $[2,6,24]$.

\section{BRD4 and transcription initiation}

Transcription initiation begins with the recruitment of RNA-PolII on the preinitiation complex (PIC) at the gene promoter, followed by RNA-PolII phosphorylation at Serine 5 and stabilization of the RNA-PolIIpromoter interaction. PIC assembly is widely influenced by ENHs and controlled by TFs and other transcription regulatory proteins [25]. Mediator of
RNA-PolII transcription (Mediator) is a large complex with modular organization which transduces signals from TFs and activators at the ENHs to promoters, timing PIC formation and transcription initiation [2628]. BRD4 has been isolated as preferred cofactor of the Mediator complex [29-31]. BRD4 and the Mediator complex have been shown to largely co-localize at active ENHs and in particular at the level of super-ENHs-SE and their genomic localization is disrupted by BET inhibition (Fig. 1a, b). Indeed, early after BETi treatment Mediator detaches by the set of regulatory elements to which is bound and its displacement tracked closely with the sensitivity of gene expression to BETi $[7,29]$. Beside highlighting the relevance of BRD4 in mediating the crosstalk between promoters and distal ENHs these data indicate that inhibition of Mediator is one of the central mechanisms underneath BETi cytotoxicity.

Many TFs and chromatin remodeling proteins have been shown to interact with BRD4 $[6,32,33]$. Since TFs are mainly associated with ENHs the interplay with these proteins is crucial for BRD4-ENHs interaction and to define BRD4 selectivity for target genes. TFs recruit acetyltransferases like p300/CBP, which in turn promote nucleosome and/or non histonic proteins (like the same TFs) acetylation. Therefore, recruitment of BRD4 to active ENHs is likely mediated by interaction with acetylated histones as well as direct binding to ENH-associated TFs [6]. Indeed, a recent model proposed that the simultaneous binding of BRD4 to histones and TFs would stabilize TFs binding to ENHs maintaining elevated the transcriptional activity of these elements. The interaction of BRD4 with TFs and histone modifiers can be either mediated by BDs and therefore dependent on the acetylation status of TFs [32, 34, 35] or by other BRD4 domains, thus being not affected by BETi treatment [33, 36, 37]. It has been shown that the ET domain of BRD4 is involved in transcriptional regulation by interacting with histone modifiers including the arginine demethylase JMJD6 [36], the lysine methyltransferase NSD3 and the nucleosome remodeling enzymes SWIF/SNF and CDH4 [37]. Through these interactions BRD4 facilitates transcriptional activation by de-compacting chromatin and accelerating messenger RNA synthesis. Using a yeast purified FLAG-tagged BRD4, Wu and colleagues performed an unbiased biochemical screening looking for BRD4 interactors [33]. Beside identifying consolidated BRD4 partners and many chromatin modifiers, these Authors demonstrated that BRD4 associates in a BD independent mode with a selected group of TFs including p53, YY1, AP2, c-JUN, C/EBP $\alpha$ and $\beta$ and the heterodimer c-MYC/MAX. BRD4 interaction with p53 is mediated by two regions outside the BDs and in part 
Table 1 Key BRD4 target genes in normal and tumor cells

\begin{tabular}{|c|c|c|c|}
\hline & Gene function & Model & Reference \\
\hline \multicolumn{4}{|c|}{ Embryonic cells } \\
\hline Oct4 & Embryonic development and stem cells pluripotency & mESC & Di Micco R, et al. Cell Rep 2014 [17] \\
\hline Xite & Regulator of $X$ - chromosome inactivation & mESC & Di Micco R, et al. Cell Rep 2014 [17] \\
\hline Tsix & Regulator of X-chromosome inactivation & mESC & Di Micco R, et al. Cell Rep 2014 [17] \\
\hline Nanog & Embryonic stem cells proliferation and pluripotency & mESC & Wu T, et al. Stem Cell Report 2015 [19] \\
\hline Sox2 & $\begin{array}{l}\text { Embryonic development and determination of } \\
\text { cells fate }\end{array}$ & mESC & Wu T, et al. Stem Cell Report 2015 [19] \\
\hline \multicolumn{4}{|c|}{ Osteogenesis } \\
\hline TNFRSF11B & Regulator of osteoblasts differentiation & hFOB & $\begin{array}{l}\text { Najafova Z, et al. Nucleic Acids Res } \\
2017 \text { [22] }\end{array}$ \\
\hline RUNX2 & $\begin{array}{l}\text { Regulator of osteoblastic differentiation and skeletal } \\
\text { morphogenesis }\end{array}$ & hFOB & $\begin{array}{l}\text { Najafova Z, et al. Nucleic Acids Res } \\
2017 \text { [22] }\end{array}$ \\
\hline ALPL & Regulator of osteoblasts differentiation & hFOB & $\begin{array}{l}\text { Najafova Z, et al. Nucleic Acids Res } \\
2017 \text { [22] }\end{array}$ \\
\hline \multicolumn{4}{|c|}{ Adipogenesis } \\
\hline Pparg & Regulator of adipocytes differentiation & mESC & Lee JE, et al. Nat Commun 2017 [21] \\
\hline Cebpa & Regulator of adipocytes differentiation & mESC & Lee JE, et al. Nat Commun 2017 [21] \\
\hline Fabp4 & Regulator of fatty acids uptake and metabolism & mESC & Lee JE, et al. Nat Commun 2017 [21] \\
\hline \multicolumn{4}{|l|}{ Myogenesis } \\
\hline Myod1 & Regulator of muscle cells differentiation & mESC & Lee JE, et al. Nat Commun 2017 [21] \\
\hline \multicolumn{4}{|c|}{ Somatic cells } \\
\hline AURKB & Mediator of cell cycle progression & $\begin{array}{l}\text { Human Foreskin } \\
\text { Keratinocytes }\end{array}$ & You J, et al. Mol Cell Biol 2009 [89] \\
\hline Ran & Regulator of cell cycle progression & Mouse Fybroblast & Dey A, et al. Mol Biol Cell 2009 [14] \\
\hline Kif5b & Regulator of cell cycle progression & Mouse Fybroblast & Dey A, et al. Mol Biol Cell 2009 [14] \\
\hline Tgf1 & Regulator of cell cycle progression & Mouse Fybroblast & Dey A, et al. Mol Biol Cell 2009 [14] \\
\hline Ywhah & Regulator of cell cycle progression & Mouse Fybroblast & Dey A, et al. Mol Biol Cell 2009 [14] \\
\hline Gnb1 & Regulator of cell cycle progression & Mouse Fybroblast & Dey A, et al. Mol Biol Cell 2009 [14] \\
\hline $\operatorname{Rad} 21$ & Regulator of cell cycle progression & Mouse Fybroblast & Dey A, et al. Mol Biol Cell 2009 [14] \\
\hline Ctnnd1 & Regulator of cell cycle progression & Mouse Fybroblast & Dey A, et al. Mol Biol Cell 2009 [14] \\
\hline Topo1 & Regulator of cell cycle progression & Mouse Fybroblast & Dey A, et al. Mol Biol Cell 2009 [14] \\
\hline \multicolumn{4}{|c|}{ Neuron cells } \\
\hline Fos & Regulation of synaptic plasticity in neurons & Mouse Neurons & Korb E, et al. Nat Neurosci 2015 [90] \\
\hline Arc & Regulation of synaptic plasticity in neurons & Mouse Neurons & Korb E, et al. Nat Neurosci 2015 [90] \\
\hline Nr4a1 & Regulation of synaptic plasticity in neurons & Mouse Neurons & Korb E, et al. Nat Neurosci 2015 [90] \\
\hline \multicolumn{4}{|c|}{ Cardiac cells } \\
\hline Nppa & Cardiovascular homeostasis & Rat cardiac Myocytes & Stratton MS, et al. Cell Rep 2016 [91] \\
\hline $\mathrm{Nppb}$ & Cardiovascular homeostasis & Rat cardiac Myocytes & Stratton MS, et al. Cell Rep 2016 [91] \\
\hline Ctgf & $\begin{array}{l}\text { Chondrocyte proliferation } \\
\text { and differentiation }\end{array}$ & Rat cardiac Myocytes & Stratton MS, et al. Cell Rep 2016 [91] \\
\hline Pln & Cardiovascular homeostasis & Rat cardiac Myocytes & Stratton MS, et al. Cell Rep 2016 [91] \\
\hline Myh6/7 & Components of cardiac muscle & Rat cardiac Myocytes & Stratton MS, et al. Cell Rep 2016 [91] \\
\hline \multicolumn{4}{|l|}{ Cancer cells } \\
\hline C-MYC & Proto-oncogene & Multiple Myeloma & Lovén J, et al. Cell 2013 [7] \\
\hline IGLL5 & Regulator of immune response & Multiple Myeloma & Lovén J, et al. Cell 2013 [7] \\
\hline IRF4 & Interferon regulatory factor & Multiple Myeloma & Lovén J, et al. Cell 2013 [7] \\
\hline
\end{tabular}


Table 1 Key BRD4 target genes in normal and tumor cells (Continued)

\begin{tabular}{|c|c|c|c|}
\hline & Gene function & Model & Reference \\
\hline $\mathrm{XBP1}$ & Post-translational Regulation & Multiple Myeloma & Lovén J, et al. Cell 2013 [7] \\
\hline PRDM1 & Regulator of immune response & Multiple Myeloma & Lovén J, et al. Cell 2013 [7] \\
\hline PIM2 & Proto-oncogene & Retinoblastoma & $\begin{array}{l}\text { Rahman S, et al. Mol Cell Biol } 2011 \\
\text { [37] }\end{array}$ \\
\hline CCND1 & Regulator of cell cycle progression & Retinoblastoma & $\begin{array}{l}\text { Rahman S, et al. Mol Cell Biol } 2011 \\
\text { [37] }\end{array}$ \\
\hline DCPS & Regulator of mRNA processing & Retinoblastoma & $\begin{array}{l}\text { Rahman S, et al. Mol Cell Biol } 2011 \\
\text { [37] }\end{array}$ \\
\hline TERT & Regulator of Telomere Homeostasis & Colon Cancer & $\begin{array}{l}\text { Akincilar SC, et al. Cancer Discov } 2016 \\
\text { [80] }\end{array}$ \\
\hline GABPA & Regulator of Mitochondrial function & Colon Cancer & $\begin{array}{l}\text { Akincilar SC, et al. Cancer Discov } 2016 \\
\text { [80] }\end{array}$ \\
\hline KRAS & Proto-oncogene & Glioblastoma & Du Z, et al. Int J Oncol 2018 [92] \\
\hline BRAF & Proto-oncogene & Glioblastoma & Du Z, et al. Int J Oncol 2018 [92] \\
\hline CALM2 & $\begin{array}{l}\text { Regulator of cell cycle progression } \\
\text { and proliferation }\end{array}$ & Glioblastoma & Du Z, et al. Int J Oncol 2018 [92] \\
\hline ARAF & Proto-oncogene & Glioblastoma & Du Z, et al. Int J Oncol 2018 [92] \\
\hline MAPK8 & $\begin{array}{l}\text { Regulator of proliferation, differentiation, } \\
\text { transcription and development }\end{array}$ & Glioblastoma & Du Z, et al. Int J Oncol 2018 [92] \\
\hline PLCB3 & Regulator of signal transduction & Glioblastoma & Du Z, et al. Int J Oncol 2018 [92] \\
\hline MAPK10 & $\begin{array}{l}\text { Regulator of proliferation, differentiation, } \\
\text { transcription and development }\end{array}$ & Glioblastoma & Du Z, et al. Int J Oncol 2018 [92] \\
\hline ADCY6 & Regulator of signal transduction & Glioblastoma & Du Z,et al. Int J Oncol 2018 [92] \\
\hline RUNX2 & $\begin{array}{l}\text { Regulator of cell proliferation, survival } \\
\text { and invasiveness }\end{array}$ & Thyroid, Breast Cancer & $\begin{array}{l}\text { Sancisi V, et al. Nucleic Acids Res } 2017 \\
\text { [11] }\end{array}$ \\
\hline FOSL1 & $\begin{array}{l}\text { Regulator of cell proliferation, } \\
\text { differentiation and trasformation }\end{array}$ & Non Small Cell Lung Cancer & Shi J, et al. Molecular Cell 2014 [6] \\
\hline $\mathrm{BCL} 2$ & Regulator of apoptosis & Hematological malignancies & Shi J, et al. Molecular Cell 2014 [6] \\
\hline XRCC5 & Involved in DSB DNA repair & Prostate Cancer & Li XY, et al. Cell Rep 2018 [58] \\
\hline XRCC4 & Involved in DSB DNA repair & Prostate Cancer & Li XY, et al. Cell Rep 2018 [58] \\
\hline NHEJ1 & Involved in DSB DNA repair & Prostate Cancer & Li XY, et al. Cell Rep 2018 [58] \\
\hline WRN & $\begin{array}{l}\text { Involved in DNA repair and } \\
\text { maintenance of genome stability }\end{array}$ & Prostate Cancer & Li XY, et al. Cell Rep 2018 [58] \\
\hline DCLRE1C & Involved in DSB DNA repair & Prostate Cancer & Li XY, et al. Cell Rep 2018 [58] \\
\hline LIG4 & Involved in DSB DNA repair & Prostate Cancer & Li XY, et al. Cell Rep 2018 [58] \\
\hline ERCC4 & Involved in DNA repair & Prostate Cancer & Li XY, et al. Cell Rep 2018 [58] \\
\hline HMOX1 & Involved in oxidative stress response & Prostate Cancer & $\begin{array}{l}\text { Hussong H, et al. Cell Death Dis } 2014 \\
\text { [93] }\end{array}$ \\
\hline SESN3 & Involved in oxidative stress response & Prostate Cancer & $\begin{array}{l}\text { Hussong H, et al. Cell Death Dis } 2014 \\
\text { [93] }\end{array}$ \\
\hline HDAC6 & Hystone Deacetylase & Prostate Cancer & $\begin{array}{l}\text { Hussong H, et al. Cell Death Dis } 2014 \\
\text { [93] }\end{array}$ \\
\hline KEAP1 & Involved in oxidative stress response & Prostate Cancer & $\begin{array}{l}\text { Hussong H, et al. Cell Death Dis } 2014 \\
\text { [93] }\end{array}$ \\
\hline MAPK3 & $\begin{array}{l}\text { Regulator of proliferation, differentiation, } \\
\text { transcription and development }\end{array}$ & Prostate Cancer & $\begin{array}{l}\text { Hussong H, et al. Cell Death Dis } 2014 \\
\text { [93] }\end{array}$ \\
\hline VIM & Involved in maintenance of cell integrity & Prostate Cancer & $\begin{array}{l}\text { Hussong H, et al. Cell Death Dis } 2014 \\
\text { [93] }\end{array}$ \\
\hline
\end{tabular}

NF-kB signaling pathway genes

TNFa Proinflammatory cytokine 
Table 1 Key BRD4 target genes in normal and tumor cells (Continued)

\begin{tabular}{|c|c|c|c|}
\hline & Gene function & Model & Reference \\
\hline & & Akute Myeloid Leukemia & \\
\hline E-Selectin & Inflammatory response mediator & Non Small Cell Lung Cancer & Huang B, et al. Mol Cell Biol 2009 [32] \\
\hline IL8 & Inflammatory response mediator & THP1 & Huang B, et al. Mol Cell Biol 2009 [32] \\
\hline \multicolumn{4}{|c|}{ Estrogen receptor target genes } \\
\hline GREB1 & Involved in response to estrogen signalling & $\begin{array}{l}\text { Endometrial and breast } \\
\text { cancer }\end{array}$ & Nagarajan S, et al. Cell Rep 2014 [94] \\
\hline TFF1 & Involved in response to estrogen signalling & $\begin{array}{l}\text { Endometrial and breast } \\
\text { cancer }\end{array}$ & Nagarajan S, et al. Cell Rep 2014 [94] \\
\hline \multicolumn{4}{|c|}{ Androgen receptor target genes } \\
\hline PSA & $\begin{array}{l}\text { Biomarker of prostatic carcinoma } \\
\text { released in seminal plasma }\end{array}$ & Prostate Cancer & Urbanucci A, et a Cell Rep 2017 [95] \\
\hline CAMKK2 & Regulator of signal transduction & Prostate Cancer & Urbanucci A, et a Cell Rep 2017 [95] \\
\hline UBE2C & $\begin{array}{l}\text { Involved in protein ubiquitination } \\
\text { regulating cell cycle progression }\end{array}$ & Prostate Cancer & Urbanucci A, et a Cell Rep 2017 [95] \\
\hline HOXB13 & $\begin{array}{l}\text { Transcription factor involved in } \\
\text { embryonal development }\end{array}$ & Prostate Cancer & Urbanucci A, et a Cell Rep 2017 [95] \\
\hline AURKA & Mediator of cell cycle progression & Prostate Cancer & Urbanucci A, et a Cell Rep 2017 [95] \\
\hline
\end{tabular}

regulated by casein kinase (CK2) mediated phosphorylation. CK2 phosphorylates BRD4 in an acidic region juxtaposed to BDs enabling BRD4 loading on DNA and interaction with p53. The selective binding with certain TFs as well as the possible modulation of these interactions by signaling pathways, have major implication in dictating BRD4 specificity for its target genes and may strongly contribute to BRD4 contextdependent functions. Indeed, Najafova and colleagues, studying osteoblast differentiation, showed that BRD4 is enriched at putative osteoblast specific distal ENHs where BRD4 colocalizes specifically with a restricted set of TFs including C/EBPb, TEAD1, FOSL2 and JUND [22]. Also in acute myeloid leukemia, BRD4 has been shown to co-localize and cooperate with hematopoietic TFs (including PU.1, FLI1, ERG, C/EBP $\alpha, C / E B P \beta$, and MYB) in conjunction with the lysine acetyltransferase p300/CBP to support lineage-specific transcriptional circuits in this disease [38]. BRD4 has been also shown as necessary coactivator of the inflammatory transcriptional program driven by NF- $\mathrm{KB}$ by binding to acetylated RelA $[32,34]$ and of a diacetylated form of TWIST in triple negative breast cancer. Beside controlling protein coding genes, BRD4 also regulates transcription of ENH-associated RNA (eRNAs) [39]. Many active ENHs have been shown to be site of active transcription for short (less than $200 \mathrm{nt}$ ) and bidirectional RNAs, which in turn assist ENHs in promoting target genes expression [40, 41]. Inhibition of BRD4 by BETi treatment has been shown to consistently repress the expression of a pool of eRNAs transcribed from BRD4 enriched ENHs. Treatment with BETi disassociates BRD4 from target ENHs abolishing BRD4-RNAPolII interaction at these sites reducing
RNA-PolII recruitment with consequent inhibition of eRNA synthesis [39]. Promoting ENHs active transcription, BRD4 fosters ENHs activity not only through an architectural remodeling.

\section{BRD4 and transcription elongation}

RNA-PolII pausing at promoter-proximal regions and its release into active transcription are a major rate limiting steps of gene expression [25]. Release of RNA-PolII into active transcription is mediated by the positive transcription elongation factor-b (P-TEFb) complex, comprising cyclin T1 (CCNT1) and cyclin-dependent kinase 9 (CDK9). In its active form, P-TEFb complex interacts with TFs and cofactors, phosphorylates pausing factors (like the Negative Elongation Factor complex NELF) displacing their binding from chromatin, and phosphorylates the carboxy-terminal domain (CTD) of RNA-PolII at Serine 2 activating transcription [25]. Among the 3 ubiquitously expressed BRD proteins, BRD4 is the only one able to interact with $\mathrm{p}-\mathrm{TEFb}$ through its $\mathrm{C}$-terminal domain [14, $16,42-45]$. Interaction with BRD4 prevents P-TEFb binding to the inhibitory ribonucleoprotein complex 7SK/ HEXIM that sequesters P-TEFb in its inactive form [43, 45]. Accumulation of BRD4 on hyper-acetylated and transcriptionally active TSSs serves as docking sites for $\mathrm{P}$-TEFb which in turns facilitates activation of RNA-PolII and its release into active elongation. Recent evidence indicates that also ENH-associated BRD4, through its interaction with JMJD6, influences P-TEFb activity promoting elongation [36]. JMJD6 colocalizes with BRD4 selectively on a definite set of active distal ENHs characterized by high levels of H3K4Me1 and H3K27Ac and named anti-pause ENHs. BRD4 mediates JMJD6 recruitment on 


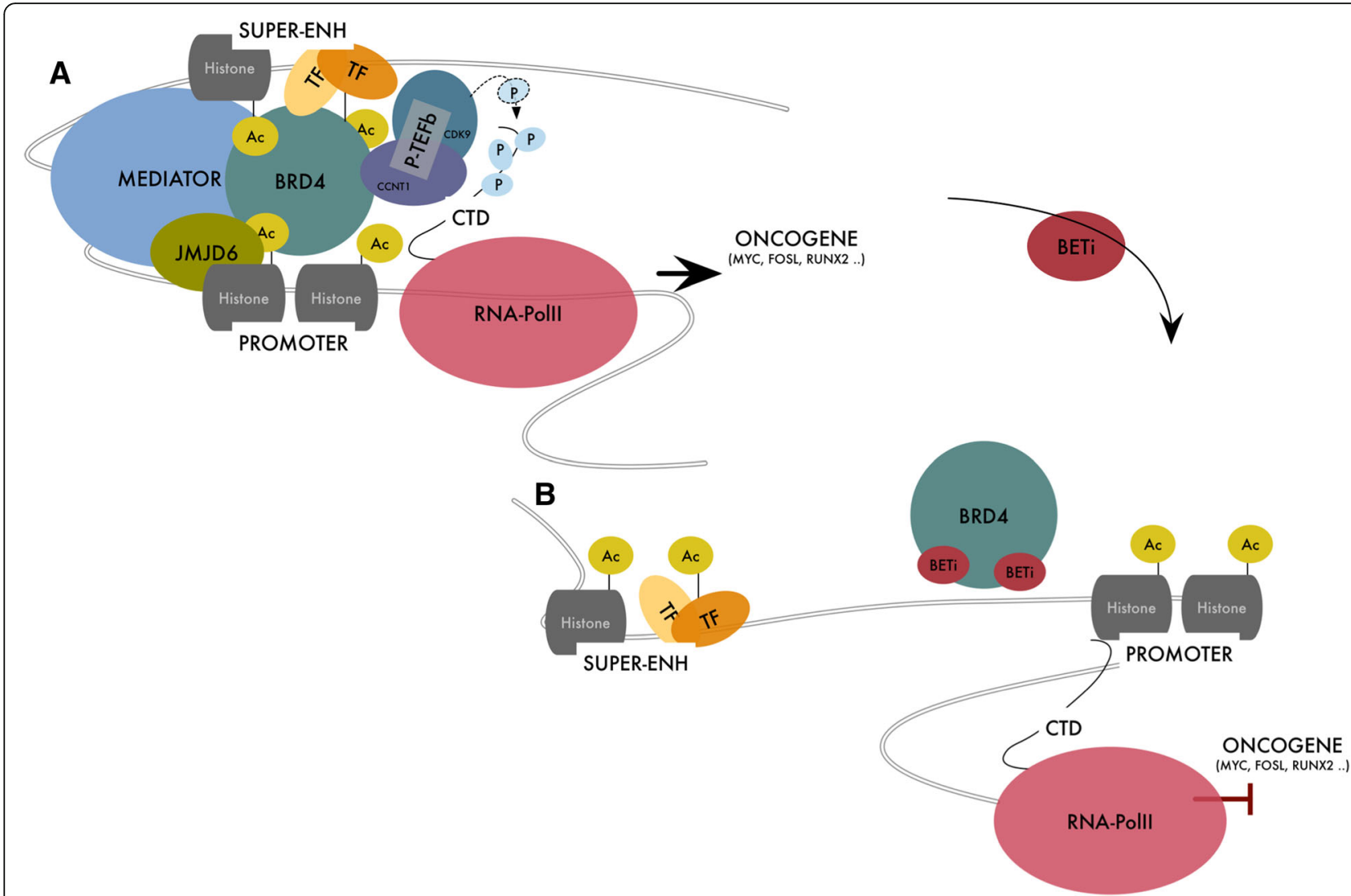

Fig. 1 a Schematic representation of BRD4 function in the organization and assembly of SE. Binding to hyperacetylated chromatin regions, BRD4 recruits the Mediator complex promoting the assembly of a large platform of transcription regulating proteins, that forms a bridge between SE and Promoter, favoring and stabilizing the binding of RNA-PollI. BRD4 also interacts and activates P-TEFb stimulating transition of RNA-Polll into active elongation. $\mathbf{b}$ Effect BETi on SE organization. BETi compete with acetylated residues for the binding at the BRD4 bromodomains releasing BRD4 from chromatin and disassembling the interaction between SE and promoter, reducing RNA-Polll throughput and blocking transcription of key oncogenes

these sites that in turns 1 . demethylates $\mathrm{H} 4$ arginine 3 mono- and dimethylated (H4R3me1, H4R3me2) which are associated with transcription repression, 2. demethylates the 5 '-methyl-phosphate cap of 7SK RNA causing its degradation and promoting local activation of P-TEFb. Long range chromatin looping mediates the effect of ENH-associated BRD4/JMJD6/P-TEFb complex on RNA-PolII release at TSS of target genes. Nucleosomes can also impede RNA-PolII progression along the gene body reducing transcript elongation and gene expression [36]. A recent report by Kanno and colleagues showed that BRD4 facilitates RNA-PolII transition along the gene body in a P-TEFb independent manner, further promoting transcript elongation [39]. These Authors showed that BRD4 beside being enriched on active promoters and ENHs is bound along the body of highly transcribed genes. Gene expression alterations following BRD4 inhibition either by BETi or BRD4 silencing largely correlate with BRD4 localization along gene bodies. This indicates that the removal of BRD4 from these genes has deleterious consequences for the RNA-PolII processivity. BRD4 follows RNA-PolII during elongation since abrogation of transcription by Actinomycin-b dramatically reduces the amount of BRD4 bound along target genes. Based on this evidence the Authors proposed that BRD4 functions as chaperone that taking advantage of its ability to interact with acetylated histones facilitates the passage of RNA-PolII through hyperacetylated nucleosomes [39]. Linked to the effect of BRD4 on transcription elongation, Donato et al. recently proposed a compensatory mechanism that may affect BETi gene target selectivity. They indicated that BETi unsensitive genes can compensate the impairment of transcription elongation induced by BRD4 inhibition by increasing RNA-PolII recruitment at TSS and transcription initiation. This is not possible for BRD4-addicted genes which have already maximized the amount of RNA-PolII loaded at TSS, to sustain the high rate of required transcription. The block of transcription elongation imposed by BRD4 inhibition impedes promoter clearance and further recruitment of RNA-PolII conferring selective susceptibility to BETi to highly expressed genes [46]. 
In addition to function as scaffolding platform for a variety of TFs and transcription related proteins, BRD4 has been shown to directly affect RNA-PolII activity by its intrinsic kinase and acetyl-transferase activity [47-49].

BRD4 directly stimulates RNA-PolII CTD domain phosphorylation at Serine 2 triggering productive transcription $[49,50]$. Noticeably, BRD4-mediated RNA-PolII phosphorylation results in the specific activation of Topoisomerase I which associates with RNA-PolII during transcription progression favoring DNA unwinding and RNA-PolII transition [51]. Furthermore, BRD4 has been shown to phosphorylate CDK9 (of the P-TEFb complex) regulating its enzymatic activity. As histone acetyltransferase (HAT) BRD4 has been shown to acetylate histones $\mathrm{H} 3$ and $\mathrm{H} 4$ with a distinct pattern, different from those of classical HATs. BRD4 acetylates H3 K122 resulting in nucleosome eviction and chromatin deconstruction leading to increased transcription [47].

\section{BRD4 and super-ENHs (SEs): Defining the molecular bases of BETi cancer specificity}

Considered the centrality and the multifunctional role that BRD4 plays in transcription regulation it is not surprising that BETi represent an attracting strategy in cancer therapy. However, while the successful employment of these drugs is moving faster from selected MYC-addicted hematological malignancies to solid cancers, questions about cancer specific susceptibility to these drugs still remain. Gene expression profiles showed that BRD4 is expressed in a broad range of somatic cells. As well, ChIP seq data showed that BRD4 occupies many ENHs and promoters also in non-cancer cells and generally contributes to gene expression (Table 1) [6]. Thus, how inhibition of a global chromatin regulator as BRD4 may results in a such cancer selective targeting, it remains at least in part unclear. The recent discovery of SEs suggests that BETi cancer specificity may be a matter of quantity [7, 52]. SEs are large clusters of ENHs closely spaced in genome that possess unique functional properties distinguishing them from regular ENHs [52]. These regions show a density of transcription factors and regulators binding as well as a quantity of H3K27Ac and $\mathrm{H} 3 \mathrm{~K} 3 \mathrm{Me} 1$ that surmount of one order of magnitude the one detected on regular ENHs. In cancer, SEs are central to maintain cell identity and are deputy to drive the expression of specific oncogenes to which cancer cells become highly addicted. Genome-wide studies indicated that SEs mark lineage specific TFs and oncogenes in a wide range of cancer type, revealing that these structures are acquired during tumorigenesis and are unique to cancer cells while largely absent in untrasformed cells $[7,53,54]$.
Thus, shortcutting the functional organization of these structures causes a dramatic drop in oncogenes expression and consequential cancer cells growth inhibition or death.

In the attempt of defining the molecular mechanisms beyond the cancer cytotoxicity of BETi in Multiple Myeloma (MM), Loven and colleagues showed that BRD4, together with Mediator, and P-TEFb is heavily accumulated on SEs and that BETi causes a preferential loss of BRD4 at these elements. Inhibition of BRD4 then resulted in loss of SEs function with consequent transcription elongation defects and block of oncogenes expression including c-MYC or other SEs associated MM relevant genes such as IGLL5, IRF4 and XBP1 [7]. At SEs, BRD4, together with Mediator, acts as the catalyst of the assembly of a cooperative and synergistic high density transcriptional complexes changing structure, dynamics and function of chromatin. Sabari and colleagues recently investigated the biophysical nature of SEs showing that these elements exhibit properties of liquid-like condensates. They showed that accumulation of BRD4 and Mediator at SEs forms nuclear puncta and gives rise to phase-separated droplets that compartmentalize and concentrate the transcription apparatus favoring protein crosstalk and interplay [55]. In such environment, inhibition of BRD4 has greater consequences that on regular ENHs conferring to SE-associated genes a higher magnitude of susceptibility to BETi and explaining at least in part the cancer selective activity of these drugs (Fig. 1b).

\section{BRD4 and DNA damage}

Perturbations of DNA double strand breaks (DSBs) repair contributes to genome instability and cancer development [56]. Alterations in the chromatin structure, largely mediated by histone posttranslational modifications, are implicated in the initiation and propagation of DNA damage response [57]. BRD4 reader of the chromatin state and pivot of chromatin organization has recently been proposed as major player in the DNA damage repair and propagation, to which it contributes through both canonical and unconventional mechanisms. Besides being a master regulator of many genes part of the DNA repair system or involved in DNA damage checkpoint activation, BRD4 also contributes to DNA damage repair in a transcriptionally independent manner.

In particular, two distinct papers reported that BRD4 is necessary for the correct activation of the Non Homologus End Joining (NHEJ) recombination pathway $[58,59]$. Stanlie et al. reported that in B lymphocyte, BRD4 is required during immunoglobulin (Ig) isotype switching for completion of class switch recombination after DSBs by Activation Induced cytidine Deaminase (AID) [59]. Li et al. also showed that BRD4 
is required for repair of DNA DSBs induced by ionizing radiation (IR) and promotes gene rearrangements in prostate cancer cells. In presence of induced DSBs (for example by IR) BRD4 inhibition, either by BETi or specific silencing, resulted in enhanced phosphorylated $\mathrm{H} 2 \mathrm{AX}(\gamma \mathrm{H} 2 \mathrm{AX})$ and persistence of DNA damage favoring genomic catastrophe and ultimately cell death [58]. In both works, the effect of BRD4 on DNA repair system, was not dependent on BRD4 transcriptional activity, but on its ability of forming a platform between histone modifications and components of the DNA repair machinery (Fig. 2a).

Mechanistically, DNA DSBs are accompanied by increased $\mathrm{H} 4$ acetylation (H4Ac) and phosphorylation of $\mathrm{H} 2 \mathrm{AX}(\gamma \mathrm{H} 2 \mathrm{AX})$. Accumulation of these modifications at both ends of the breaks induces BRD4 recruitment that in turn works as docking sites for the DNA repair complex (Fig. 2a).

Among many DNA repair components that show interaction with BRD4 in co-immunoprecipitation experiments, both works identified the p53 Binding Protein (53BP1) as major binding partner of BRD4 in DNA damage repair regulation $[58,59] .53 \mathrm{BP} 1$ is a large protein of 1972 amino acids that has no apparent enzymatic activity but when recruited to DSB specific histone code acts as a molecular scaffold that recruits additional DSB-responsive proteins to damaged chromatin [60, 61].

Using sequential Chromatin Immune Precipitation experiments, Li et al. demonstrated that pharmacological inhibition or silencing of BRD4 abolish 53BP1 recruitment to IR induced DSB. By contrast, silencing of 53BP1 does not affect BRD4 binding in the same condition, demonstrating that hierarchically BRD4 functions upstream of 53BP1 and serves as a bookmark to guide this protein on DSB sites. Even if further evidence is needed, it is likely that the interaction with BRD4 at DSBs serves to stabilize the binding of 53BP1 with DNA repair complexes on site, in a model that tightly resembles the mechanism of action of BRD4 in stabilizing transcriptional machinery at enhancers and promoters during transcription [58] (Fig. 2a-b). Besides, BRD4, relying on its enzymatic activities, could promote acetylation or phosphorylation of DNA repair proteins stimulating their cooperation. This may lead to the formation of dense multi-protein

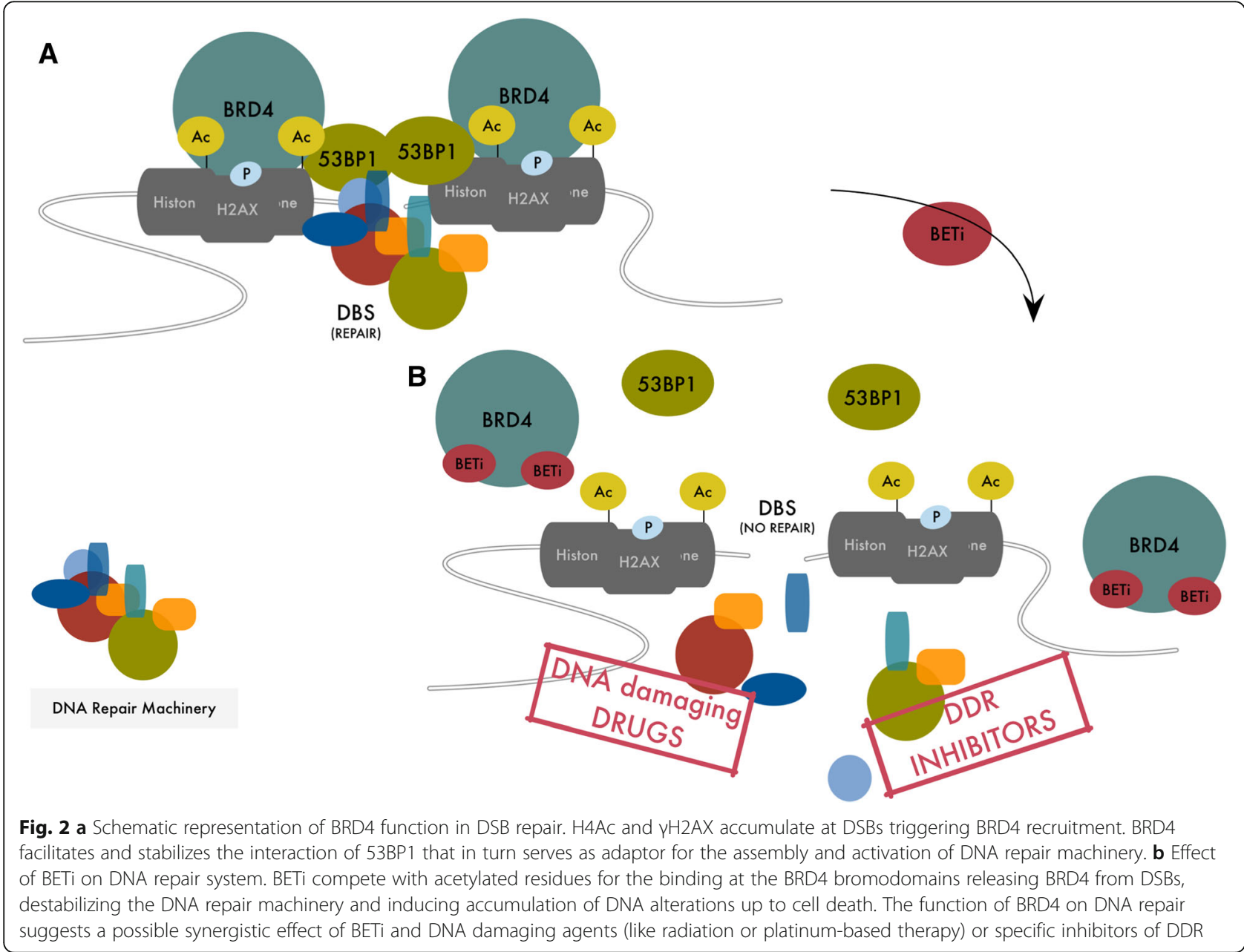


complexes that change the physical status of chromatin (liquid-liquid phase separation) resembling the model already proposed for super-enhancers [55].

In addition to its role in promoting NHEJ activity, BRD4 has been also implicated in the activation of DNA damage checkpoint $[62,63]$.

Replication stress, induced among the others by oncogene increased transcription or DNA replication, is a complex phenomenon which has serious implications for genome stability [64]. Generation of aberrant replication fork structures exposes single-stranded DNA which in turn activates the replication stress response including the Ataxia Telangiectasia And Rad3-Related (ATR)- Checkpoint kinase 1 (CHK1) kinase axes [65]. Malfunctioning of the DNA damage checkpoint leads indeed to collapse of replication fork, DNA DSB and chromosome rearrangement [66]. Evidence exists that BRD4 associates with chromatin at the level of replication forks. Zhang and colleagues showed that BRD4 interacts with several components of the DNA pre-replication complex and regulates activation of DNA damage response in a transcriptionally independent way. The Cell Division Cycle 6 (CDC6), licensing factor of DNA replication initiation, is crucial for BRD4 function in this process. BRD4 inhibition either by BETi or specific silencing caused defective DNA damage checkpoint sensitizing cells to stress-inducing agents [63].

Partially in contraposition with these data, Floyd and colleagues showed that a specific isoform (iso B) of BRD4 functions as endogenous inhibitor of DNA damage response, insulating chromatin from DNA damage response propagation. In response to induced DNA damage, increased association of BRD4 Iso B with chromatin is observed. In turn, BRD4 isoB recruits Structural Maintenance of Chromosomes 2 and 4 (SMC2, SMC4), components of the condensing II complex inducing chromatin condensation. Inhibition of this BRD4 variant induces relaxed chromatin structure and enhanced survival after irradiation. Of note, Iso $B$ lacks the C-terminal domain through which BRD4 interacts with p-TEF and is necessary for its transcriptional activity [62]. This structural difference may account at least in part for this peculiar function of BRD4.

The functional involvement of BRD4 in DNA damage checkpoint activation and DNA repair holds relevant implications for cancer therapy and envisages new settings for the employment of BETi both alone or in combination.

Targeting DNA damage repair (DDR) pathways is a promising therapeutic strategy in treating cancer with defective DDR components [67]. Indeed, PARP inhibitors have shown solid anti-tumor activity in the treatment of BRCA1 and BRCA2 mutated ovarian and breast cancers [68-70]. As well, ATR and CHK1 inhibitors have shown selective cytotoxic effects on Cyclin E1 (CCNE1) overexpressing cancer due to the high dependency of these tumors on the ATR/CHK1 axis [71]. The evidence that BRD4 positively regulates DNA damage checkpoint activation and DSB repair, implicates that its pharmacological inhibition by BETi may increase sensitivity of cancer cells to DDR or ATR inhibitors defining a possible combination strategy in specific tumor settings. Indeed, a recent report showed that BRD4 inhibition by BETi induces recombination deficiency and sensitize cancer cells to PARP inhibitors regardless of BRCA1/2, p53 and RAS/RAF mutational status. These results not only demonstrate the synergistic effects of BETi in combination with DDR targeting agents but also imply the possibility of extending PARPi efficacy to non BRCA1/2 mutated cancers through the employment of BETi [72]. Finally, the evidence that BETi treatment impairs DSB repair indicates that these drugs may also improve cytotoxic effects of DNA damaging agents like radiation or platinum-based chemotherapy.

\section{BRD4 and telomere regulation}

Telomeres sense somatic cells aging by shortening at each mitosis and induce cell death when they become critically short. Thus, progressive reduction of telomere length is a rate limiting step for uncontrolled and unlimited cell proliferation capacity. Aberrant telomere elongation and alterations in Telomerase expression and/or activity are functional to cancer aggressiveness $[6,73]$. Telomerase Reverse Transcriptase (TERT) is the catalytic subunit of Telomerase complex and together with its RNA template, the Telomerase RNA Component (TERC), are considered the limiting components of this complex [74]. Recently, independent reports highlighted a possible role of BRD4 in aberrant telomere regulation in cancer, even if the mechanisms through which BRD4 cooperates to telomere elongation is still poorly defined. First, BRD4 has been implicated in the aberrant transcriptional regulation of TERT, in TERT promoter mutated tumors. Recently, two recurrent mutations within the TERT promoter have been identified and associated with aggressiveness and poor prognosis in many types of cancer [75-79]. These mutations $(-124$ bp $\mathrm{C}>\mathrm{T}$ and $-146 \mathrm{bp} \mathrm{C}>\mathrm{T}$ upstream the TSS) represent the most prevalent non-coding alterations in cancer and create aberrant binding sites for E-Twenty-Six (ETS) TFs within the promoter, leading to increased TERT expression [77, 78]. Ankillar et al. using Circular Chromosome Conformation Capture (4C) and Chromatin Conformation Capture (3C), showed that the ETS factor GABPA binds specifically to mutant TERT promoter mediating long-range chromatin interaction and enrichment of 
active histone marks, driving TERT transcription. Furthermore the presence of GABPA at mutated promoter leads to an enrichment of active histone marks, and consequently drives TERT transcription [80]. According to these authors, BRD4 cooperates to this process through both a direct and an indirect mechanism. Directly BRD4 accumulates on TERT mutated promoter by binding to hyperacetylated histones and participates to the stabilization of the long-range chromatin interactions promoted by GABPA. Furthermore, BRD4 binds to GABPA promoter driving its transcription and fueling indirectly the transcriptional organization at the TERT mutated promoter resulting in increased TERT expression.

Treatment with BETi as well as BRD4 knock-down result in a significant reduction of TERT expression and impairment of Telomerase activity together with a significant decrease in the recruitment of histone active marks and long range chromatin interaction specifically in TERT promoter mutated cells. Consistently, CRISPR-mediated reversal of mutant TERT promoter or deletion of its long-range chromatin interaction, abrogates GABPA binding and long-range chromatin interactions, causing a loss of active histone marks and RNA-PolII recruitment with a consequent decrease of TERT transcription [80]. In addition to its function in promoting TERT expression, a non-transcriptional role of BRD4 in telomere homeostasis regulation has been proposed [81]. Using an unbiased screening based on a lentiviral shRNAs library targeting 706 known kinases and relative genes, BRD4 has been identified as necessary for telomere maintenance in cancer cells. Treatment with four different BRD4 pharmacological inhibitors, including OTX015, induced a dosedependent telomere lengthening inhibition. Long-term

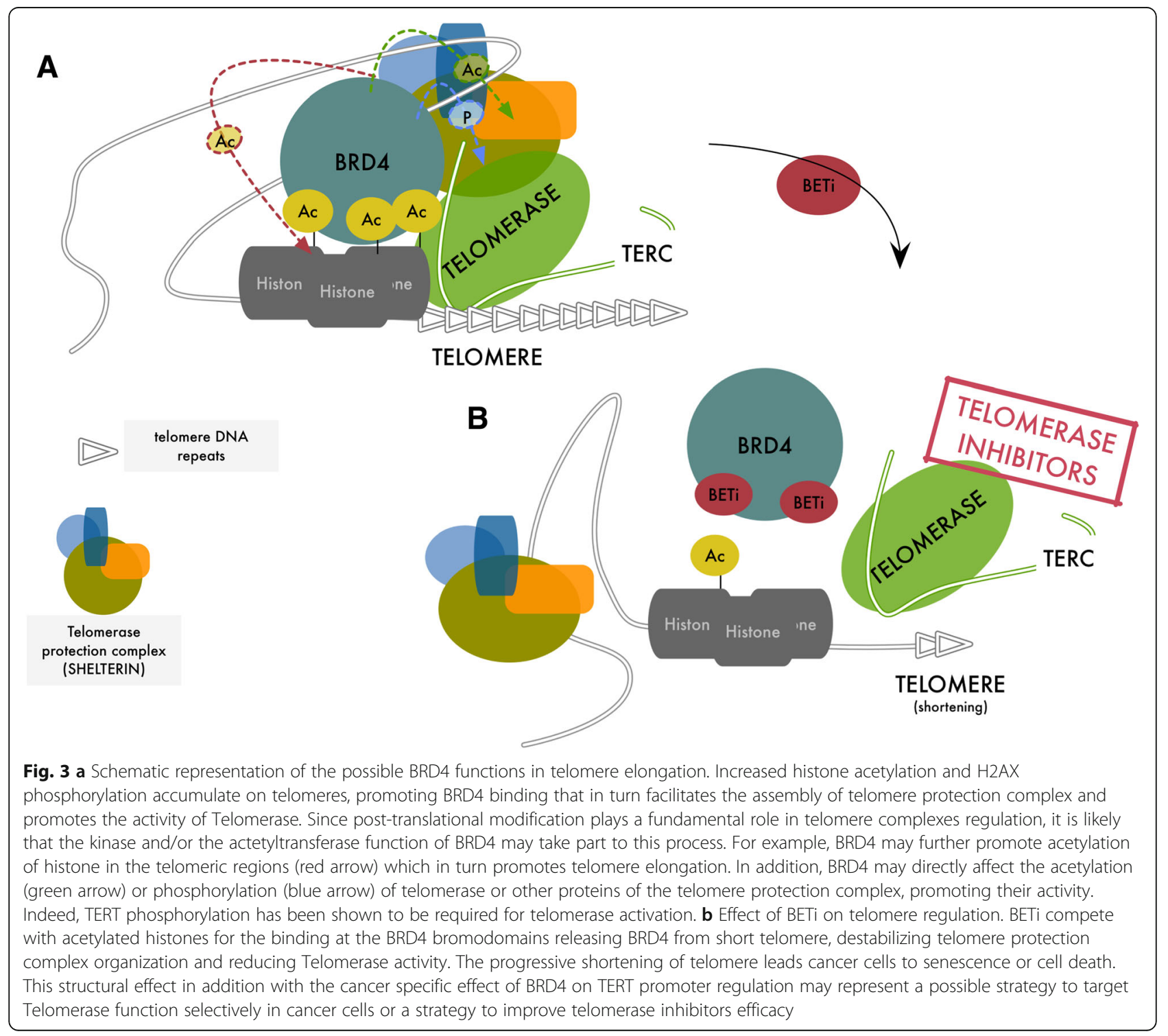


BRD4 inhibition caused telomere shortening which was sufficient to cause telomere dysfunction and chromosomal fusion leading to cell death. Noticeably, this effect is not-dependent on Telomerase expression or enzymatic activity since BRD4 inhibition leads to telomere alterations even in experiments conducted in artificial cellular systems where TERT and TERC are exogenously overexpressed [81].

How BRD4 orchestrates telomere maintenance is not fully defined. Short telomeres are characterized by increased histone acetylation and H2AX phosphorylation [82]. Since Telomerase complex preferentially acts on short telomere [83, 84], we may speculate that, BRD4 acts as a platform to recruit and stabilize the binding of the Telomerase complex and/or other telomere-associated complexes promoting telomeres lengthening by accumulating to hyper-acetylated histones at the end of chromosomes [83] (Fig. $3 \mathrm{a}$-b). Consistently, it has been demonstrated that treatment with HDAC inhibitors increases histone acetylation levels at telomere and enhances elongation also in absence of TERC (even if in minor extent), while HAT inhibition induces telomere shortening leading to telomere loss [85].

Targeting telomerase and telomere aberrant regulation has been long regarded as a promising anti-cancer strategy and Telomerase inhibitors have shown effectiveness in reducing cancer cell viability, tumor growth and metastasis in preclinical studies. However, these drugs lack sufficient cancer specificity and failed clinical trials due to high side effects toxicity [86-88]. The relevance of BRD4 in controlling TERT expression selectively in presence of cancer-associated promoter mutations, seems to suggest that inhibition of BRD4 by BETi could represent an alternative and more selective inhibition of telomerase. Besides, possible combination with BETi could improve effectiveness of telomerase inhibitors at lower doses, reducing the magnitude of undesired side effects.

\section{Conclusion}

Accumulating evidence identifies BRD4 as master keeper of genome function and stability and underlines a common model of action across many processes in which BRD4 is involved. Reading the histone code, BRD4 senses hyper-acetylated chromatin sites (like enhancers, DSBs or telomeres) and accumulates on these loci favoring the recruitment and the stabilization of functionally relevant multiprotein complexes. The high-density protein binding changes chromatin physical status and creates separated functional domains optimizing proteins crosstalk and function.

The uprising evidence of the transversal centrality of BRD4 in many cancer supporting processes provides new interpretation for the cytotoxic activity of BETi and in particular envisages new and wide possibilities for the clinical employment of these drugs in cancer settings.

\section{Abbreviations}

53BP1: p53 Binding Protein; AID: Activation Induced cytidine Deaminase; ATR: Ataxia Telangiectasia And Rad3-Related kinase; BD: Bromodomain; BETi: Bromodomain and Extraterminal inhibitor; BRCA1, BRCA2: Breast Related Cancer Antigens; BRD (1-4): Bromodomain-containing protein (1-4); CCNE1: Cyclin E1; CCNT1: Cyclin T1; CDC6: Cell Division Cycle 6; CDK9: Cyclin-dependent kinase 9; CEBP: Ccaat-enhancer-binding proteins; CHD4: Chromodomain Helicase DNA Binding Protein 4; CHK1: Checkpoint kinase 1; CK2: Casein kinase 2; CTD: Carboxy-terminal domain; DDR: DNA damage repair; DSBs: DNA double strand breaks; ENH: Enhancer; ERG: ETSrelated gene; eRNA: Enhancer RNA; ET: Extraterminal domain; ETS: E-Twenty-Six; FLI1: Friend leukemia integration 1 transcription factor; GABPA: GA-binding protein alpha; $\mathrm{YH} 2 \mathrm{AX}$ : phosphorylated Histone 2AX; H3K27Ac: Histone 4 Lysine 27 Acetylated; H3K4me1: Histone 4 Lysine 3 monomethylated; H4AC: Histone 4 acetylation; H4R3me1: Histone 4 Arginine 3 monomethylated; H4R3me2: Histone 4 Arginine 3 dimethylated; HAT: Histone acetyltransferase; IGLL5: Immunoglobulin lambda like polypeptide 5; IR: Ionizing radiation; IRF4: Interferon regulatory factor 4; JMJD6: Jumonji Domain-Containing Protein 6; MED 1: Mediator-1; NELF: Negative Elongation Factor; NFKB: Nuclear factor kappa-light-chain-enhancer of activated B cells; NHEJ: Non Homologus End Joining; NSD3: Nuclear Receptor Binding SET Domain Protein 3; p300/ CBP: p300/ CREB-binding protein; PARPi: Poli ADP-ribosio polimerasi inhibitors: PIC: Prelnitation Complex; P-TEFb: Positive transcription elongation factor-b; RNA-Polll: RNA- Polimerase II; SE: Super-Enhancer; SMARCA4 SWI/SNF: Related, matrix associated, actin dependent regulator of chromatin, subfamily a, member 4; SMC2, SMC4: Structural Maintenance of Chromosomes 2 and 4; TEAD1: Transcriptional enhancer factor TEF-1; TERC: Telomerase RNA Component; TERT: Telomerase Reverse Transcriptase; TF: Transcription Factor; TSS: Transcription Starting Site; XBP1: X-box binding protein 1

\section{Acknowledgements}

We wish to thank all members of the Lab for useful discussion.

Funding

No funding

Availability of data and materials

Not applicable

Authors' contributions

$\mathrm{BD}, \mathrm{EL}$ and $\mathrm{AC}$ wrote the manuscript. All Authors have reviewed and approved the final manuscript.

Ethics approval and consent to participate

Not applicable

Consent for publication

Not applicable

Competing interests

The authors declare that they have no competing interests.

\section{Publisher's Note}

Springer Nature remains neutral with regard to jurisdictional claims in published maps and institutional affiliations.

Received: 10 August 2018 Accepted: 7 November 2018

Published online: 22 November 2018

\section{References}

1. Dhalluin C, Carlson JE, Zeng L, He C, Aggarwal AK, Zhou MM. Structure and ligand of a histone acetyltransferase bromodomain. Nature. 1999:399:491-6.

2. Wu SY, Chiang CM. The double bromodomain-containing chromatin adaptor Brd4 and transcriptional regulation. J Biol Chem. 2007;282:13141-5.

3. Zeng L, Zhou MM. Bromodomain: an acetyl-lysine binding domain. FEBS Lett. 2002;513:124-8

4. Filippakopoulos P, Picaud S, Mangos M, Keates T, Lambert JP, BarsyteLovejoy D, Felletar I, Volkmer R, Muller S, Pawson T, et al. Histone recognition and large-scale structural analysis of the human bromodomain family. Cell. 2012;149:214-31. 
5. Moriniere J, Rousseaux S, Steuerwald U, Soler-Lopez M, Curtet S, Vitte AL, Govin J, Gaucher J, Sadoul K, Hart DJ, et al. Cooperative binding of two acetylation marks on a histone tail by a single bromodomain. Nature. 2009:461:664-8.

6. Shi J, Vakoc CR. The mechanisms behind the therapeutic activity of BET bromodomain inhibition. Mol Cell. 2014;54:728-36.

7. Loven J, Hoke HA, Lin CY, Lau A, Orlando DA, Vakoc CR, Bradner JE, Lee TI, Young RA. Selective inhibition of tumor oncogenes by disruption of superenhancers. Cell. 2013;153:320-34.

8. Dawson MA, Prinjha RK, Dittmann A, Giotopoulos G, Bantscheff M, Chan WI, Robson SC, Chung CW, Hopf C, Savitski MM, et al. Inhibition of BET recruitment to chromatin as an effective treatment for MLL-fusion leukaemia. Nature. 2011;478:529-33.

9. Delmore JE, Issa GC, Lemieux ME, Rahl PB, Shi J, Jacobs HM, Kastritis E, Gilpatrick T, Paranal RM, Qi J, et al. BET bromodomain inhibition as a therapeutic strategy to target c-Myc. Cell. 2011;146:904-17.

10. Filippakopoulos P, Qi J, Picaud S, Shen Y, Smith WB, Fedorov O, Morse EM, Keates T, Hickman TT, Felletar I, et al. Selective inhibition of BET bromodomains. Nature. 2010;468:1067-73.

11. Sancisi V, Manzotti G, Gugnoni M, Rossi T, Gandolfi G, Gobbi G, Torricelli F, Catellani F, Faria do Valle I, Remondini D, et al. RUNX2 expression in thyroid and breast cancer requires the cooperation of three non-redundant enhancers under the control of BRD4 and c-JUN. Nucleic Acids Res. 2017;45:11249-67.

12. Zhao Y, Liu Q, Acharya P, Stengel KR, Sheng Q, Zhou X, Kwak H, Fischer MA, Bradner JE, Strickland SA, et al. High-resolution mapping of RNA polymerases identifies mechanisms of sensitivity and resistance to BET inhibitors in t(8;21) AML. Cell Rep. 2016;16:2003-16.

13. Dey A, Ellenberg J, Farina A, Coleman AE, Maruyama T, Sciortino S, Lippincott-Schwartz J, Ozato K. A bromodomain protein, MCAP, associates with mitotic chromosomes and effects, G(2)-to-M transition. Mol Cell Biol. 2000;20:6537-49.

14. Dey A, Nishiyama A, Karpova T, McNally J, Ozato K. Brd4 Marks select genes on mitotic chromatin and directs Postmitotic transcription. Mol Biol Cell. 2009;20:4899-909.

15. Mochizuki K, Nishiyama A, Jang MK, Dey A, Ghosh A, Tamura T, Natsume H, Yao HJ, Ozato K. The bromodomain protein Brd4 stimulates $\mathrm{G}(1)$ gene transcription and promotes progression to $\mathrm{S}$ phase. J Biol Chem. 2008;283:9040-8

16. Yang $Z Y, H e N H$, Zhou Q. Brd4 recruits P-TER to chromosomes at late mitosis to promote $\mathrm{G}(1)$ gene expression and cell cycle progression. Mo Cell Biol. 2008;28:967-76.

17. Di Micco R, Fontanals-Cirera B, Low V, Ntziachristos P, Yuen SK, Lovell CD, Dolgalev I, Yonekubo Y, Zhang GT, Rusinova E, et al. Control of embryonic stem cell identity by BRD4-dependent transcriptional elongation of superenhancer-associated pluripotency genes. Cell Rep. 2014;9:234-47.

18. Liu W, Stein P, Cheng X, Yang W, Shao NY, Morrisey EE, Schultz RM, You J. BRD4 regulates Nanog expression in mouse embryonic stem cells and preimplantation embryos. Cell Death Differ. 2014;21:1950-60.

19. Wu T, Pinto HB, Kamikawa YF, Donohoe ME. The BET family member BRD4 interacts with OCT4 and regulates pluripotency gene expression. Stem Cell Reports. 2015;4:390-403.

20. Houzelstein D, Bullock SL, Lynch DE, Grigorieva EF, Wilson VA, Beddington RSP. Growth and early postimplantation defects in mice deficient for the bromodomain-containing protein Brd4. Mol Cell Biol. 2002;22:3794-802.

21. Lee JE, Park YK, Park S, Jang Y, Waring N, Dey A, Ozato K, Lai B, Peng WQ, Ge K. Brd4 binds to active enhancers to control cell identity gene induction in adipogenesis and myogenesis. Nat Commun. 2017;8:2217.

22. Najafova Z, Tirado-Magallanes R, Subramaniam M, Hossan T, Schmidt G, Nagarajan S, Baumgart SJ, Mishra VK, Bedi U, Hesse E, et al. BRD4 localization to lineage-specific enhancers is associated with a distinct transcription factor repertoire. Nucleic Acids Res. 2017;45:127-41.

23. Wu SY, Lee AY, Hou SY, Kemper JK, Erdjument-Bromage H, Tempst P, Chiang CM. Brd4 links chromatin targeting to HPV transcriptional silencing. Genes Dev. 2006;20:2383-96.

24. Devaiah BN, Gegonne A, Singer DS. Bromodomain 4: a cellular Swiss army knife. J Leukoc Biol. 2016;100:679-86.

25. Jonkers I, Lis JT. Getting up to speed with transcription elongation by RNA polymerase II. Nat Rev Mol Cell Biol. 2015;16:167-77.

26. Allen BL, Taatjes DJ. The mediator complex: a central integrator of transcription. Nat Rev Mol Cell Biol. 2015;16:155-66.
27. Flanagan PM, Kelleher RJ 3rd, Sayre MH, Tschochner H, Kornberg RD. A mediator required for activation of RNA polymerase II transcription in vitro. Nature. 1991;350:436-8.

28. Kelleher RJ 3rd, Flanagan PM, Kornberg RD. A novel mediator between activator proteins and the RNA polymerase II transcription apparatus. Cell. 1990;61:1209-15.

29. Bhagwat AS, Roe JS, Mok BYL, Hohmann AF, Shi JW, Vakoc CR. BET Bromodomain inhibition releases the mediator complex from select cisregulatory elements. Cell Rep. 2016;15:519-30.

30. Donner AJ, Ebmeier CC, Taatjes DJ, Espinosa JM. CDK8 is a positive regulator of transcriptional elongation within the serum response network. Nat Struct Mol Biol. 2010;17:194-U199.

31. Jiang YW, Veschambre P, Erdjument-Bromage H, Tempst P, Conaway JW, Conaway RC, Kornberg RD. Mammalian mediator of transcriptional regulation and its possible role as an end-point of signal transduction pathways. Proc Natl Acad Sci U S A. 1998;95:8538-43.

32. Huang B, Yang XD, Zhou MM, Ozato K, Chen LF. Brd4 coactivates transcriptional activation of NF-kappaB via specific binding to acetylated RelA. Mol Cell Biol. 2009;29:1375-87.

33. Wu SY, Lee AY, Lai HT, Zhang H, Chiang CM. Phospho switch triggers Brd4 chromatin binding and activator recruitment for gene-specific targeting. Mol Cell. 2013;49:843-57.

34. Zou Z, Huang B, Wu X, Zhang H, Qi J, Bradner J, Nair S, Chen LF. Brd4 maintains constitutively active NF-kappaB in cancer cells by binding to acetylated RelA. Oncogene. 2014;33:2395-404.

35. Shi J, Wang YF, Zeng L, Wu YD, Deng J, Zhang Q, Lin YW, Li JL, Kang TB, Tao $\mathrm{M}$, et al. Disrupting the interaction of BRD4 with Diacetylated Twist suppresses tumorigenesis in basal-like breast Cancer. Cancer Cell. 2014;25:210-25.

36. Liu W, Ma Q, Wong K, Li W, Ohgi K, Zhang J, Aggarwal A, Rosenfeld MG. Brd4 and JMJD6-associated anti-pause enhancers in regulation of transcriptional pause release. Cell. 2013;155:1581-95.

37. Rahman S, Sowa ME, Ottinger M, Smith JA, Shi Y, Harper JW, Howley PM. The Brd4 Extraterminal domain confers transcription activation independent of pTEFb by recruiting multiple proteins, including NSD3. Mol Cell Biol. 2011;31:2641-52.

38. Roe JS, Mercan F, Rivera K, Pappin DJ, Vakoc CR. BET Bromodomain inhibition suppresses the function of hematopoietic transcription factors in acute myeloid leukemia. Mol Cell. 2015;58:1028-39.

39. Kanno T, Kanno Y, LeRoy G, Campos E, Sun HW, Brooks SR, Vahedi G, Heightman TD, Garcia BA, Reinberg D, et al. BRD4 assists elongation of both coding and enhancer RNAs by interacting with acetylated histones. Nat Struct Mol Biol. 2014;21:1047-57.

40. Andersson R, Gebhard C, Miguel-Escalada I, Hoof I, Bornholdt J, Boyd M, Chen Y, Zhao X, Schmidl C, Suzuki T, et al. An atlas of active enhancers across human cell types and tissues. Nature. 2014;507:455.

41. Li WB, Notani D, Ma Q, Tanasa B, Nunez E, Chen AY, Merkurjev D, Zhang J, Ohgi K, Song XY, et al. Functional roles of enhancer RNAs for oestrogendependent transcriptional activation. Nature. 2013;498:516.

42. Bisgrovet DA, Mahmoudi T, Henklein P, Verdin E. Conserved P-TEFbinteracting domain of BRD4 inhibits HIV transcription. Proc Natl Acad Sci U S A. 2007;104:13690-5.

43. Jang MK, Mochizuki K, Zhou MS, Jeong HS, Brady JN, Ozato K. The bromodomain protein Brd4 is a positive regulatory component of $\mathrm{P}$ TEFb and stimulates RNA polymerase II-dependent transcription. Mol Cell. 2005;19:523-34.

44. Schroder S, Cho SY, Zeng L, Zhang Q, Kaehlcke K, Mak L, Lau J, Bisgrove D, Schnolzer M, Verdin E, et al. Two-pronged binding with Bromodomaincontaining protein 4 liberates positive transcription elongation factor b from inactive ribonucleoprotein complexes. J Biol Chem. 2012;287:1090-9.

45. Yang Z, Yik JH, Chen R, He N, Jang MK, Ozato K, Zhou Q. Recruitment of PTEFb for stimulation of transcriptional elongation by the bromodomain protein Brd4. Mol Cell. 2005;19:535-45.

46. Donato E, Croci O, Sabo A, Muller H, Morelli MJ, Pelizzola M, Campaner S. Compensatory RNA polymerase 2 loading determines the efficacy and transcriptional selectivity of JQ1 in Myc-driven tumors. Leukemia. 2017:31:479-90.

47. Devaiah BN, Case-Borden C, Gegonne A, Hsu CH, Chen QR, Meerzaman D, Dey A, Ozato K, Singer DS. BRD4 is a histone acetyltransferase that evicts nucleosomes from chromatin. Nat Struct Mol Biol. 2016;23:540-8.

48. Devaiah BN, Lewis BA, Cherman N, Hewitt MC, Albrecht BK, Robey PG, Ozato K, Sims RJ 3rd, Singer DS. BRD4 is an atypical kinase that 
phosphorylates serine2 of the RNA polymerase II carboxy-terminal domain Proc Natl Acad Sci U S A. 2012;109:6927-32.

49. Devaiah BN, Singer DS. Cross-talk among RNA polymerase II kinases modulates C-terminal domain phosphorylation. J Biol Chem. 2012;287: 38755-66.

50. Pradhan MA, Blackford JA, Devaiah BN, Thompson PS, Chow CC, Singer DS, Simons SS. Kinetically defined mechanisms and positions of action of two new modulators of glucocorticoid receptor-regulated gene induction. J Biol Chem. 2016;291:342-54.

51. Baranello L, Wojtowicz D, Cui KR, Devaiah BN, Chung HJ, Chan-Salis KY, Guha R, Wilson K, Zhang XH, Zhang HL, et al. RNA polymerase II regulates topoisomerase 1 activity to favor efficient transcription. Cell. 2016;165:357-71.

52. Sengupta S, George RE. Super-enhancer-driven transcriptional dependencies in Cancer. Trends Cancer. 2017;3:269-81.

53. Hnisz D, Abraham BJ, Lee TI, Lau A, Saint-Andre V, Sigova AA, Hoke HA, Young RA. Super-enhancers in the control of cell identity and disease. Cell. 2013;155:934-47.

54. Hnisz D, Schuijers J, Lin CY, Weintraub AS, Abraham BJ, Lee TI, Bradner JE, Young RA. Convergence of developmental and oncogenic signaling pathways at transcriptional super-enhancers. Mol Cell. 2015;58:362-70.

55. Sabari BR, Dall'Agnese A, Boija A, Klein IA, Coffey EL, Shrinivas K, Abraham BJ, Hannett NM, Zamudio AV, Manteiga JC, et al. Coactivator condensation at super-enhancers links phase separation and gene control. Science. 2018;361.

56. Mani RS, Chinnaiyan AM. Triggers for genomic rearrangements: insights into genomic, cellular and environmental influences. Nat Rev Genet. 2010;11:819-29.

57. Misteli T, Soutoglou E. The emerging role of nuclear architecture in DNA repair and genome maintenance. Nat Rev Mol Cell Biol. 2009;10:243-54.

58. Li XY, Baek G, Ramanand SG, Sharp A, Gao YP, Yuan W, Welti J, Rodrigues DN, Dolling D, Figueiredo I, et al. BRD4 promotes DNA repair and mediates the formation of TMPRSS2-ERG gene rearrangements in prostate Cancer. Cell Rep. 2018;22:796-808.

59. Stanlie A, Yousif AS, Akiyama H, Honjo T, Begum NA. Chromatin reader Brd4 functions in Ig class switching as a repair complex adaptor of nonhomologous end-joining. Mol Cell. 2014;55:97-110.

60. Schultz LB, Chehab NH, Malikzay A, Halazonetis TD. p53 binding protein 1 (53BP1) is an early participant in the cellular response to DNA double-strand breaks. J Cell Biol. 2000;151:1381-90.

61. Wang B, Matsuoka S, Carpenter PB, Elledge SJ. 53BP1, a mediator of the DNA damage checkpoint. Science. 2002;298:1435-8.

62. Floyd SR, Pacold ME, Huang QY, Clarke SM, Lam FC, Cannell IG, Bryson BD, Rameseder J, Lee MJ, Blake EJ, et al. The bromodomain protein Brd4 insulates chromatin from DNA damage signalling. Nature. 2013;498:246.

63. Zhang JW, Dulak AM, Hattersley MM, Willis BS, Nikkila J, Wang A, Lau A, Reimer C, Zinda M, Fawell SE, et al. BRD4 facilitates replication stressinduced DNA damage response. Oncogene. 2018;37:3763-77.

64. Zeman MK, Cimprich KA. Causes and consequences of replication stress. Nat Cell Biol. 2014;16:2-9.

65. Zhou BBS, Bartek J. Targeting the checkpoint kinases: Chemosensitization versus chemoprotection. Nat Rev Cancer. 2004;4:216-25.

66. Gelot C, Magdalou I, Lopez BS. Replication stress in mammalian cells and its consequences for mitosis. Genes. 2015;6:267-98.

67. Cheung-Ong K, Giaever G, Nislow C. DNA-damaging agents in Cancer chemotherapy: serendipity and chemical biology. Chem Biol. 2013;20:648-59.

68. Ledermann JA, Harter P, Gourley C, Friedlander M, Vergote I, Rustin G, Scott C, Meier W, Shapira-Frommer R, Safra T, et al. Overall survival in patients with platinum-sensitive recurrent serous ovarian cancer receiving olaparib maintenance monotherapy: an updated analysis from a randomised, placebocontrolled, double-blind, phase 2 trial. Lancet Oncol. 2016;17:1579-89.

69. Ledermann JA, Harter P, Gourley C, Friedlander M, Vergote I, Rustin GJS, Scott CL, Meier W, Shapira-Frommer R, Safra T, et al. Overall survival (OS) in patients (pts) with platinum sensitive relapsed serous ovarian cancer (PSR SOC) receiving olaparib maintenance monotherapy: an interim analysis. J Clin Oncol. 2016;34.

70. Zimmer AS, Gillard M, Lipkowitz S, Lee JM. Update on PARP inhibitors in breast Cancer. Curr Treat Options in Oncol. 2018;19:21.

71. Toledo LI, Murga M, Zur R, Soria R, Rodriguez A, Martinez S, Oyarzabal J, Pastor J, Bischoff JR, Fernandez-Capetillo O. A cell-based screen identifies ATR inhibitors with synthetic lethal properties for cancer-associated mutations. Nat Struct Mol Biol. 2011;18:721-U124.

72. Sun $C Y$, Yin J, Fang $Y$, Chen J, Jeong $K J$, Chen $X H$, Vellano $C P$, Ju ZL, Zhao W, Zhang D, et al. BRD4 Inhibition Is Synthetic Lethal with PARP Inhibitors through the Induction of Homologous Recombination Deficiency. Cancer Cell. 2018:33:401.

73. Harley CB, Kim NW, Prowse KR, Weinrich SL, Hirsch KS, West MD, Bacchetti S, Hirte HW, Counter CM, Greider CW, et al. Telomerase, cell immortality, and Cancer. Cold Spring Harb Symp Quant Biol. 1994;59:307-15.

74. Blackburn EH. Structure and function of telomeres. Nature. 1991; 350:569-73.

75. Gandolfi G, Ragazzi M, de Biase D, Visani M, Zanetti E, Torricelli F, Sancisi V, Gugnoni M, Manzotti G, Braglia L, et al. Genome-wide profiling identifies the THYT1 signature as a distinctive feature of widely metastatic papillary thyroid carcinomas. Oncotarget. 2018;9:1813-25.

76. Gandolfi G, Ragazzi M, Frasoldati A, Piana S, Ciarrocchi A, Sancisi V. TERT promoter mutations are associated with distant metastases in papillary thyroid carcinoma. Eur J Endocrinol. 2015;172:403-13.

77. Horn S, Figl A, Rachakonda PS, Fischer C, Sucker A, Gast A, Kadel S, Moll I, Nagore E, Hemminki K, et al. TERT promoter mutations in familial and sporadic melanoma. Science. 2013;339:959-61.

78. Huang FW, Hodis E, Xu MJ, Kryukov GV, Chin L, Garraway LA. Highly recurrent TERT promoter mutations in human melanoma. Science. 2013; 339:957-9.

79. Vinagre J, Almeida A, Populo H, Batista R, Lyra J, Pinto V, Coelho R, Celestino $\mathrm{R}$, Prazeres $\mathrm{H}$, Lima $\mathrm{L}$, et al. Frequency of TERT promoter mutations in human cancers. Nat Commun. 2013;4:2185.

80. Akincilar SC, Khattar E, Boon PL, Unal B, Fullwood MJ, Tergaonkar V. Longrange chromatin interactions drive mutant TERT promoter activation. Cancer Discovery. 2016;6:1276-91.

81. Wang S, Pike AM, Lee SS, Strong MA, Connelly CJ, Greider CW. BRD4 inhibitors block telomere elongation. Nucleic Acids Res. 2017:45:8403-10.

82. Hao LY, Strong MA, Greider CW. Phosphorylation of H2AX at short telomeres in T cells and fibroblasts. J Biol Chem. 2004;279:45148-54

83. Bandaria JN, Qin PW, Berk V, Chu S, Yildiz A. Shelterin protects chromosome ends by compacting Telomeric chromatin. Cell. 2016;164:735-46.

84. Takai KK, Hooper S, Blackwood S, Gandhi R, de Lange T. In vivo stoichiometry of Shelterin components. J Biol Chem. 2010;285:1457-67.

85. Dan JM, Yang J, Liu YF, Xiao A, Liu L. Roles for histone acetylation in regulation of telomere elongation and two-cell state in mouse ES cells. J Cell Physiol. 2015;230:2337-44.

86. Chiappori AA, Kolevska T, Spigel DR, Hager S, Rarick M, Gadgeel S, Blais N, Von Pawel J, Hart L, Reck M, et al. A randomized phase II study of the telomerase inhibitor imetelstat as maintenance therapy for advanced nonsmall-cell lung cancer. Ann Oncol. 2015;26:354-62.

87. Gatzka MV. Targeted tumor therapy remixed-an update on the use of smallmolecule drugs in combination therapies. Cancers. 2018;10.

88. Mender I, Senturk S, Ozgunes N, Akcali KC, Kletsas D, Gryaznov S, Can A, Shay JW, Dikmen ZG. Imetelstat (a telomerase antagonist) exerts off-target effects on the cytoskeleton. Int J Oncol. 2013;42:1709-15.

89. You JX, Li Q, Wu C, Kim J, Ottinger M, Howley PM. Regulation of Aurora B expression by the Bromodomain protein Brd4. Mol Cell Biol. 2009;29:5094-103.

90. Korb E, Herre M, Zucker-Scharff I, Darnell RB, Allis CD. BET protein Brd4 activates transcription in neurons and BET inhibitor Jq1 blocks memory in mice. Nature Neuroscience. 2015;18:1464.

91. Stratton MS, Lin CY, Anand P, Tatman PD, Ferguson BS, Wickers ST, Ambardekar AV, Sucharov CC, Bradner JE, Haldar SM, McKinsey TA. Signaldependent recruitment of BRD4 to cardiomyocyte super-enhancers is suppressed by a MicroRNA. Cell Rep. 2016;16:1366-78.

92. Du ZH, Song XX, Yan FF, Wang JJ, Zhao YX, Liu SM. Genome-wide transcriptional analysis of BRD4-regulated genes and pathways in human glioma U251 cells. Int J Oncol. 2018;52:1415-26.

93. Hussong M, Borno ST, Kerick M, Wunderlich A, Franz A, Sultmann H, Timmermann B, Lehrach H, Hirsch-Kauffmann M, Schweiger MR. The bromodomain protein BRD4 regulates the KEAP1/NRF2-dependent oxidative stress response. Cell Death Dis. 2014;5:e1195.

94. Nagarajan S, Hossan T, Alawi M, Najafova Z, Indenbirken D, Bedi U, Taipaleenmaki H, Ben-Batalla I, Scheller M, Loges S, et al. Bromodomain protein BRD4 is required for estrogen receptor-dependent enhancer activation and gene transcription. Cell Rep. 2014;8:459-68.

95. Urbanucci A, Barfeld SJ, Kytola V, Itkonen HM, Coleman IM, Vodak D, Sjoblom L, Sheng X, Tolonen T, Minner S, et al. Androgen receptor deregulation drives Bromodomain-mediated chromatin alterations in prostate Cancer. Cell Rep. 2017;19:2045-59. 